\title{
ROMAN BONE DISTAFFS AND SPINDLES: COULD THEY HAVE BEEN USED FOR SPINNING?
}

\author{
Ilija Danković \\ Institute of Archaeology, Belgrade \\ \begin{tabular}{r|r} 
e-mail: ilija.dankovic@yahoo.de & Original scientific paper \\
Received: 8. 5. 2020. & UDC: 904:745.51(497.11)"01/02" \\
Accepted: 4.9.2020. & $904: 726.8(497.11) " 01 / 02 "$
\end{tabular}
}

\begin{abstract}
Bone spinning implements have traditionally been a neglected part of Roman material culture, due to a general lack of interest for topics outside of the so-called "male domain". The consequence of such a situation is that hand distaffs often remained unidentified, in manners that contributed to the persistence of stereotypes about women in the Roman world. The predominant occurrence of these artefacts in sepulchral contexts, as well as their supposed fragility and miniature dimensions, led some scholars to the conclusion that they had a symbolic and ritual role. On the other hand, most of bone spinning implements possess some undoubtedly functional elements. This article presents an attempt to systematize all available data on bone spinning equipment, with particular focus on the collection of distaffs and spindles from ancient Viminacium. At the current stage of research, it can be concluded that there is no compelling evidence for the use of bone spinning tools in everyday wool working in Viminacium.
\end{abstract}

Keywords: Roman wool spinning, bone distaffs, bone spindles, Viminacium

Wool had a special significance in the Roman world. The Latin word for it - lana was simultaneously used to name clothes in general (Larsson Lovén $1998,85)$. Garments worn by priests of the traditional Roman religion were exclusively made out of wool. It was also used for bands that were tied around the heads of sacrificial animals, sacred trees, altars, temple columns, etc. Wool symbolizes the correct relationship with nature because, unlike leather, it comes from an animal that continues to live (Sebesta 2001, 47).

A very important step in the process of making a finished product from the raw material was the spinning of the yarn. Equipment used for this task consisted of three implements: a distaff - colus, a spindle - fusus, and a basket for storing tools as well as rovings of unspun wool and balls of yarn - calathus (Facsády 2008, 166). A roving of wool would have been attached to a distaff held in the left hand, and from it, fibres would be extracted with two fingers. The spindle was in the right hand, and on it, there was some yarn already spun, the 


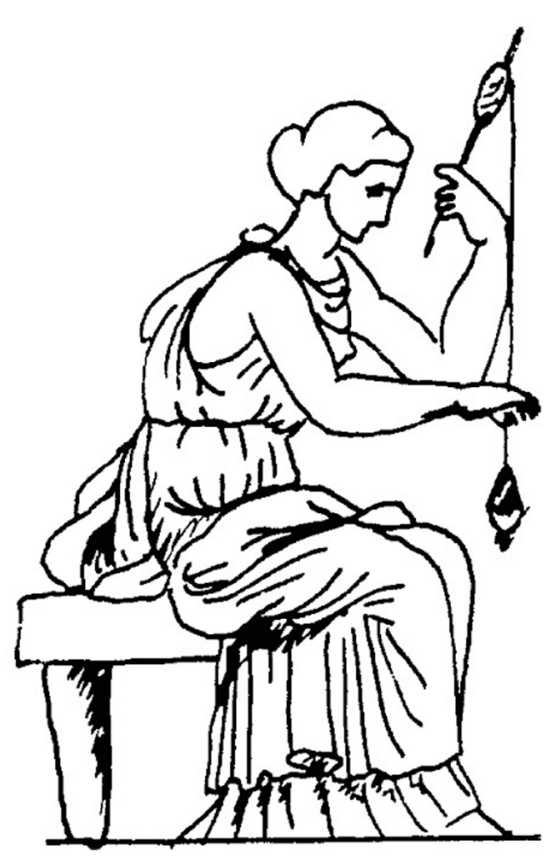

Fig. 1. A woman spinning - Part of the freeze on the temple of Minerva,

Forum Transitorium, Rome (After: Raţiu 2016, Pl. VII, 1)

Сл. 1. Жена која преде - Део фриза Минервиног храма, Нервин форум, Рим (Према: Raţiu 2016, Pl. VII, 1) end of which would be connected to the extracted fibres. At that point, the spindle would be rotated, spinning the fibres into yarn (Fig. 1). When the spindle reached the ground, the spun thread was wound around it, and the whole process could be repeated (Facchinetti 2005, 203-204).

Wool spinning, as well as weaving, was considered a woman's task, and it was expected of female members of the household to supply clothes for the family (Allason-Jones 2005, 104). In time, this task became a sort of a symbol of the entire gender, and an expression of female virtue. For this reason, epitaphs from the period of the Republic often incorporate the phrase lanam fecit ("she worked with wool"). The grave stone of a certain Claudia is a very good example of this. Passers-by are informed that she was married, pleasant to talk to, gave birth to two sons, and that she spun wool (Larsson Lovén 1998, 88). Apparently, those were the qualities that should have adorned a Roman woman. The grave stone of Allia Potestas is also quite illustrative, where it is stated:

... lana cui manibus nuncquam sine causa recessit...

... her wool never left her hands without good reason...

(CIL VI.39765).

In all probability, a developed industrial textile production must have existed by that time, which would render home manufacturing obsolete. However, a woman spinning gained metaphorical meaning in literature. Livy's story of Lucretia is perhaps the most significant in this sense. Her husband was absent because of his military obligations. During the siege of a city, he met with other commanders, Etruscan nobles, and the conversation about the merits of 


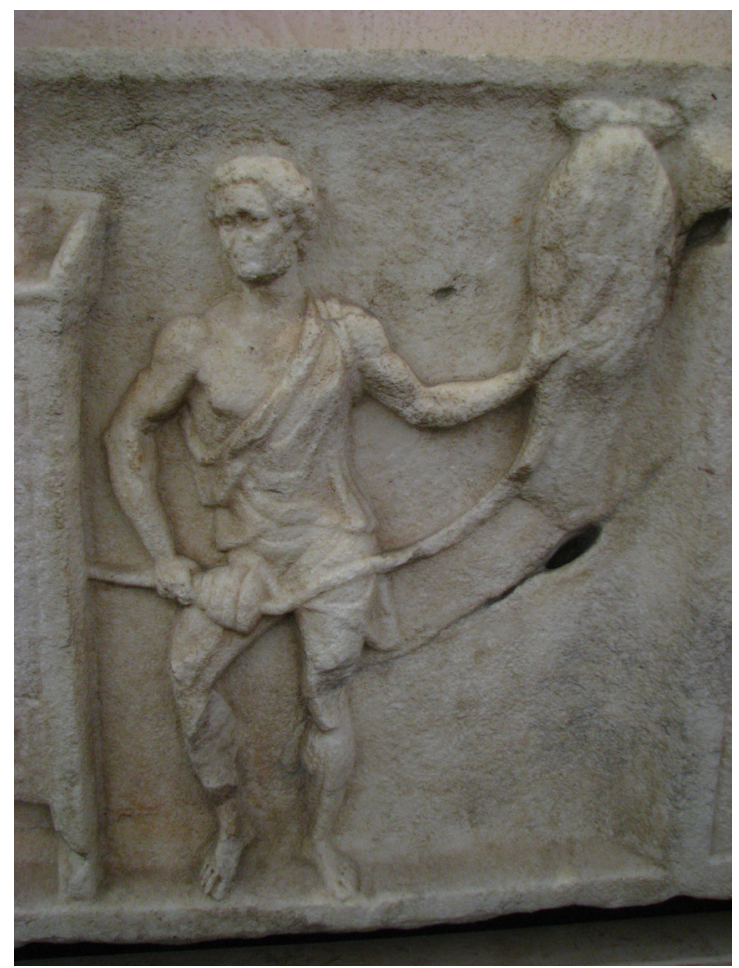

Fig. 2. A man spinning, sarcophagus, Rome (Photo: Carrol Krause)

Сл. 2. Мушкарац који преде, саркофаг, Рим (Фотографија: Керол Краус)

their wives commenced. The decision was made to pay them a surprise visit in the city of Rome, where the majority of the women were dancing and indulging themselves in leisure, while Lucretia was at home, spinning, not minding it was late at night (Thurston Peck 1898, 1526). After a few days, an Etruscan prince raped Lucretia. She made her father and brother swear an oath to avenge her, committing suicide afterward. A chain of events started by this led to the uprising against the Etruscan rule and the foundation of the Republic (D'Ambra 2007, 58). Female virtue, evoked by the wool spinning metaphor, thus lies at the very core of the story of the establishment of the Roman state.

Although Roman writers connected men to spinning in attempts to discredit, mock, and publicly shame them (Pásztókai-Szeőke 2011, 128), male individuals employed in wool working activities had to have existed. A possible confirmation for this assumption is provided by a relief decoration of a sarcophagus located in Museo Nazionale in Rome. A man engaged in spinning fibres can be clearly seen (Fig. 2), although it is most likely that this individual is spinning flax, or some other plant bast fibre, which was deemed an appropriate activity for a man. 


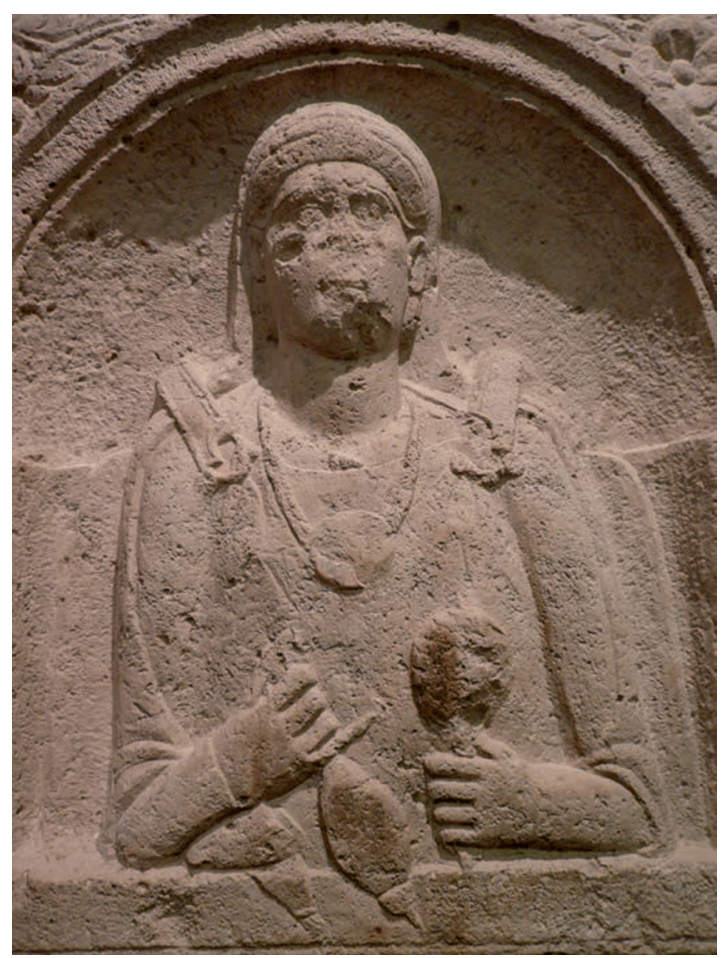

Fig. 3. Funerary portrait of Veriuga, Dunaújváros, Hungary (After: Carroll 2013, 296)

Сл. 3. Портрет Вериуге, Дунајварош, Мађарска (Према: Carroll 2013, 296)

Wool spinning was accepted as a symbol of feminine virtue across the Empire. Instead of the lanam fecit formula used in epitaphs, the custom of representing distaffs and spindles on tombstones emerged. It is important to note that the act of spinning itself is never shown, only the tools (Facsády 2008, 169), sometimes passively in the hands of the portrait of the deceased (Fig. 3). Distaffs are usually represented with rovings of wool attached to them, and the coiled yarn can be observed on spindles. Spinning implements are shown exclusively in this manner in Pannonia (Pásztókai-Szeőke 2011, 129), but there are numerous examples from the eastern Aegean area, Syria, Germania, and rarely from Britannia (Carroll 2013, 301).

The final symbolical expression of feminine virtue and care for the household are luxurious distaffs and spindles deposited in graves of deceased women. ${ }^{1}$ By rule, these rarely surpass $20 \mathrm{~cm}$ in length, which was deemed as

\footnotetext{
${ }^{1}$ A basket is sometimes shown on tombstones, placed on the ground, and storing spinning tools and yarn. Given the organic nature of materials these baskets were made of, it is uncertain if they were also deposited in graves. The find of a glass calathus inside a sarcophagus in Constanţa (Romania), together with a distaff and a spindle (Rădulescu et al. 1973, 260), tells us that baskets had to be parts of grave furnishings at least in some cases.
} 
miniature by some researchers. They were often lavish objects, manufactured from various materials such as amber, jet, ivory, glass, and sometimes precious metals. This makes them precious parts of personal belongings, which exceed their primary function, and play an important role in the construction of identity. Careful execution, fragile materials, and miniature dimension were among the reasons that led a certain number of scholars to the conclusion that these artefacts weren’t actually used for spinning (Bíró 1994, 211; Trink1 2005, 290-291; Bíró et al. 2012, 22).

Bone distaffs and spindles represent the most numerous group of Roman spinning equipment, and they provide the possibilities of discussion about their functionality the most. As will be shown, despite numerous pieces of evidence that suggest purely symbolical value and ritual nature of these objects, some of them possess certain elements that can be described as simply functional. The corpus of bone spinning tools discovered in ancient Viminacium ${ }^{2}$ will be under particular scrutiny, given that these were available to the author for a more detailed examination. Also, this archaeological site stands out due to the large quantity of these objects.

\section{Hand distaffs}

Distaffs are a heterogeneous category of artefacts. The ones that were used during everyday activities were probably made of wood, and any kind of stick or branch pronged at the top could have been used for that purpose. Due to the perishable nature of this material, only a few distaffs of this kind have been preserved to our days. ${ }^{3} \mathrm{~A}$ fragment of one has been found inside a grave in Martres-de-Veyre in France (Audollent 1923, 305). It is forked at the top, and it is also unique by the fact that unspun wool is still bound to it (Gottschalk 1996, 486).

The question that arouses is: were the objects which were used for spinning in day-to-day activities longer than specimens made from pricier materials, due to the need for placing the distaff under the armpit or resting it on the hip or waste? Historically, such distaffs are known from different societies and time periods. Their main role is to reduce the tiredness of the hand during work. Hence, this type is labelled as waist distaffs (Smith 1859, 565).

\footnotetext{
${ }^{2}$ Viminacium is located in modern-day Serbia. It was founded as a legionary fort, in which Legio VII Claudia was stationed until the Late Antiquity. Near the fort, a civil settlement emerged, which in time became an administrative centre of the province of Moesia Superior.

${ }^{3}$ Unfortunately, the wooden specimen from Viminacium (Голубовић 2000, 90-91) is nowadays known only from the sketchy description in the field journal.
} 


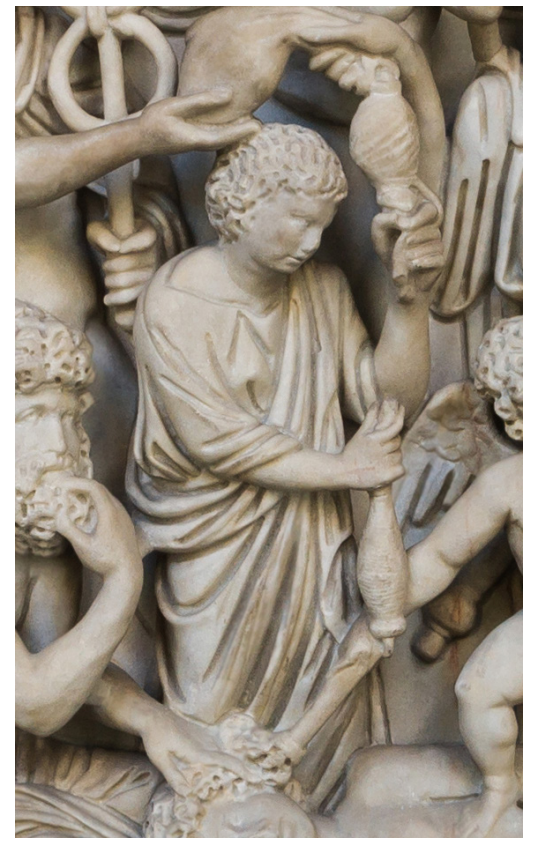

Fig. 4. Clotho spinning, sarcophagus, Museo Archeologico Nazionale di Napoli, Italy (Photo: Jebulon, Wikimedia Commons)

Сл. 4. Клото преде, саркофаг, Национални археолошки музеј у Напуљу, Италија (Фотографија: Jebulon, Wikimedia Commons)

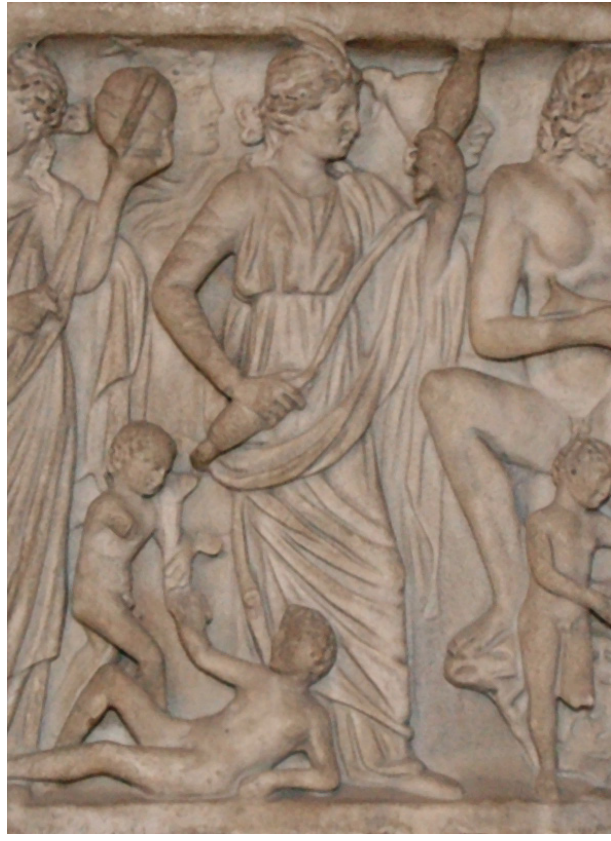

Fig. 5. Clotho spinning, sarcophagus, Louvre, France (Photo: Jastrow, Wikimedia Commons)

Сл. 5. Клото преде, саркофаг, Лувр, Француска (Фотографија: Jastrow, Wikimedia Commons)

At this place, four ivory waist distaffs need to be mentioned. Two were discovered in Cologne, one in Milan, and one in Selongey (Facchinetti 2005). These are rare proofs that significantly longer distaffs actually existed in the Roman world. A problem related to their interpretation is that visual culture originating from that period never illustrates wool working with such tools, but always with smaller hand distaffs. The truth is that scenes of women engaged in spinning are extremely rare prior to the $5^{\text {th }}$ century (Gines Taylor 2018, 47). Some of them include a relief of Minerva instructing women to spin and weave located in the Forum Transitorium (Fig. 1), a fresco of Clotho spinning, from Ostia in Italy, two sarcophagi with scenes of the creation of man, on displays in Museo Archeologico Nazionale di Napoli (Fig. 4) and the Louvre Museum (Fig. 5), respectively, a mosaic of Hercules in disguise from Valencia, etc. Although we must have in mind that an accurate representation of the spinning process and needed tools was 


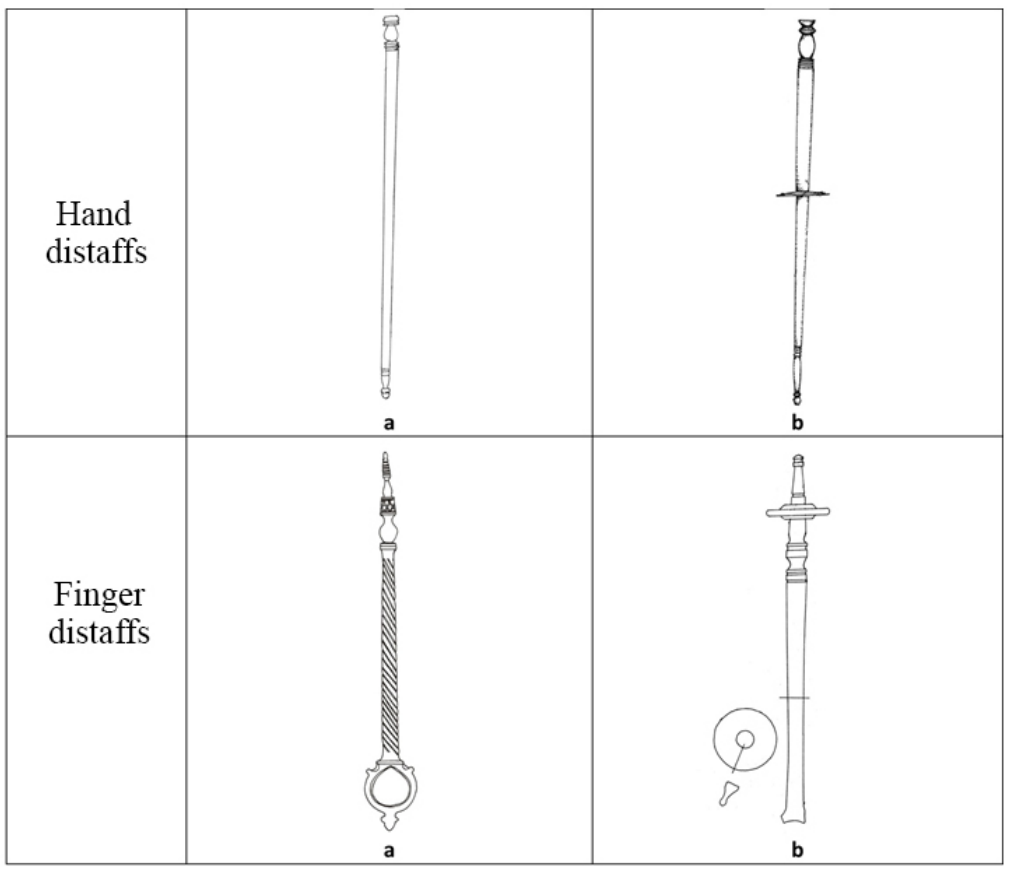

Fig. 6. Typology of bone distaffs from Viminacium (DCV)

Сл. 6. Типологија преслица од кости из Виминацијума (ДЦВ)

not the intention of artists that produced these works, distaffs on them do seem a little bit longer than the ones usually present in archaeological records.

Bone specimens discovered so far are exclusively hand distaffs, which are significantly shorter, mainly around $20 \mathrm{~cm}$ in length. These can be subdivided further, depending on the existence of a ring in the bottom part of the object, intended to secure a better grip during work. If this was the case, they are called finger distaffs. Figure 6 shows that bone distaffs from Viminacium conform to general typology, with the existence of subtypes defined by the presence or absence of a central disc, the functionality of which will be addressed in this paper. ${ }^{4}$

As it has already been stated, bone specimens represent by far the most numerous group of Roman distaffs discovered on archaeological sites across the Empire. For a long time, these artefacts have been interpreted in various ways in

\footnotetext{
${ }^{4}$ Specimens labelled as hand distaffs in Fig. 6 have been interpreted as spindles in some cases (Pásztókai-Szeöke, Radman-Livaja 2013, 263, Kat.23.20). On the other hand, Grazia Facchinetti recognizes these artefacts as distaffs of the IIa type (Facchinetti 2005, 221). Indeed, this particular wooden object was found inside a grave in Viminacium alongside a spindle (Fig. 8), thus completing the wool spinning kit. We should, however, acknowledge the possibility of regional patterns in the usage of these objects.
} 
scholarly papers, ${ }^{5}$ most often as toiletry spatulas or cosmetic rods for extraction and smearing of perfume oils and ointments (Шарановић-Светек 1981, 156; T II, 11,12; T IV, 7; Petković 1995, 35-36; Korać, Golubović 2009, 61-62). Another fairly common stance was that they represent decorative hairpins (Зотовић, Јордовић 1990; Јевремовић 1996). In rare cases, distaffs are described as fan handles or spindles (Микулчић 1975, 91-94), or even as distaff-spindles (Спасић-Ђурић 2007, 182), which is a non-existing category. ${ }^{6}$

Ethno-archaeological and archaeological testaments, primarily the material culture discovered in sepulchral contexts, as well as depictions on numerous tombstones, have greatly contributed the discarding of alternative interpretations, and archaeological community nowadays is unanimous in the identification of these artefacts as distaffs. A. Wasowitz $(1987,268-278)$ was the first researcher to point out similarities between modern-day distaff in Bulgaria and the ones from different eras, including those from classical Antiquity. M. T. Bíró expanded such interpretations further, suggesting that those with figural depictions were not used as tools (Bíró 1994, 208-212). Given that a large number of bone finger distaffs originates from the territory of modern-day Turkey, it can be assumed that it is indeed one of these represented on the funerary altar displayed in the İzmir Museum (Trinkl 2000), as well as on the sarcophagus discovered in Ephesus (Trinkl 1994), as implied by a clearly recognizable ring at the bottom parts of objects. Furthermore, amongst other furnishing deposited in this sarcophagus, containing remains of a young pregnant woman and a child, a distaff, a spindle, and several spindle whorls were discovered (Fig. 7).

On the cemeteries of Viminacium, there are four examples of distaffs and spindles being deposited together (Fig. 8), and in two more cases, a spindle whorl was present beside a distaff. This implies that it was a custom to bury a complete spinning kit with the deceased, but because of different circumstances,

\footnotetext{
${ }^{5}$ This is also true for distaffs made of other materials. The glass ones have most often been identified as pestles for grinding cosmetics, medicines, or pigments for painting, while distaffs with figural decorations have been seen as hairpins, votive objects, or cosmetic rods (Ružić 1994, 56; Ропкић 2006; Facsády 2008, 165; Стаменковић et al. 2016, 30, Сл. 16). Specimens from Cologne have even been identified as strigils (Fremersdorf, Polonyi-Fremersdorf 1984, 111-112). Amber distaffs have been identified as scented sticks lit during funeral ceremonies or as cosmetic rods for putting on perfumes (Gagetti 2006, 146). Other authors recognize them as sceptres, i.e. regard them as insignias of power. In several cases, they have been interpreted as fan handles (Aurisicchio et al. 2002, 108). Identifying the original purpose of this type of artefacts isn't the problem only of Roman archaeology, but also of that of the Early Byzantine period. Distaffs have been identified as cult objects related to the followers of the heresy of Bonus, anointing equipment, or cosmetic rods (Špehar 2010, 106).

${ }^{6}$ As a result, finger distaffs are commonly drawn or photographed upside down, with the ring shown at the top, especially when being interpreted as cosmetic rods for smearing perfumes.
} 

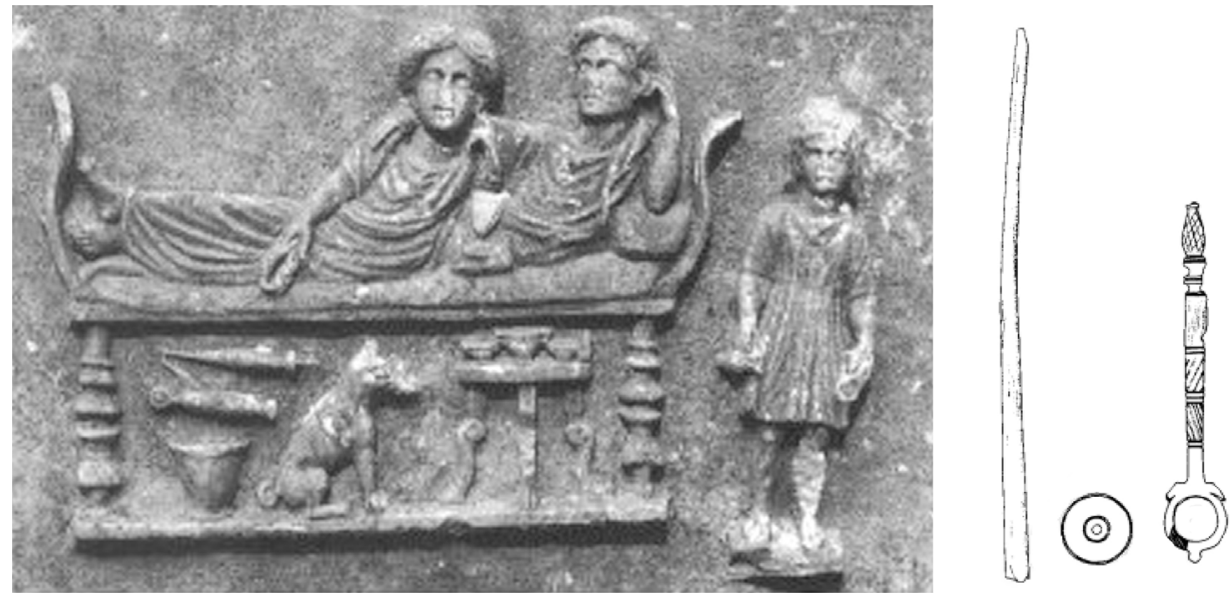

Fig. 7. a) Scene depicted on the sarcophagus from Ephesus, Turkey;

b) Spinning equipment found inside the sarcophagus (After: Trinkl 1994)

Сл. 7. а) Представа покојнице на саркофагу из Ефеса у Турској,

b) Прибор за предење откривен унутар саркофага (Према: Trinkl 1994)

it hasn't always survived to modern times. The first reason is the possibility that a fair number of these objects was made out of wood, which most often completely deteriorates. Wooden hand distaffs are known from Viminacium (Голубовић 2000, 90-91), and Nowy Łowicz (Poland), where it incorporated an amber and a glass bead (Gottschalk 1996, 486). Another important circumstance is the fact that the majority of discovered objects originates from graves of cremated individuals and there is a possibility that spinning implements had been destroyed by fire on the funeral pyre. Indeed, traces of burning are clearly visible on many distaffs. Figure 9 shows a bone and a glass specimen which were exposed to high temperatures.

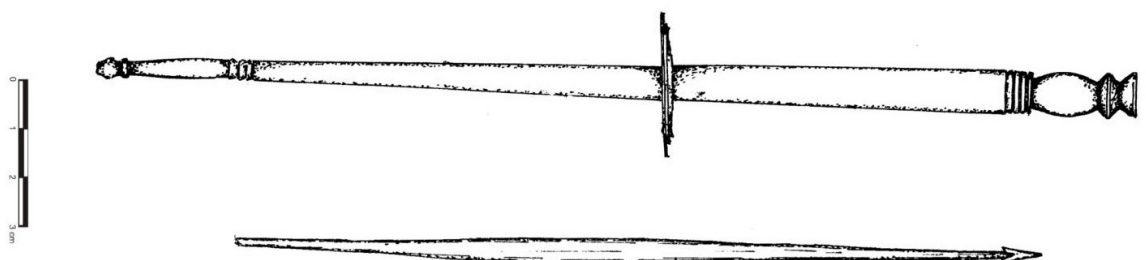

Fig. 8. Bone distaff and spindle from a grave discovered in Viminacium, Serbia (DCV) Сл. 8. Преслица и вретено од кости откривени скупа у гробу, Виминацијум (ДЦВ) 

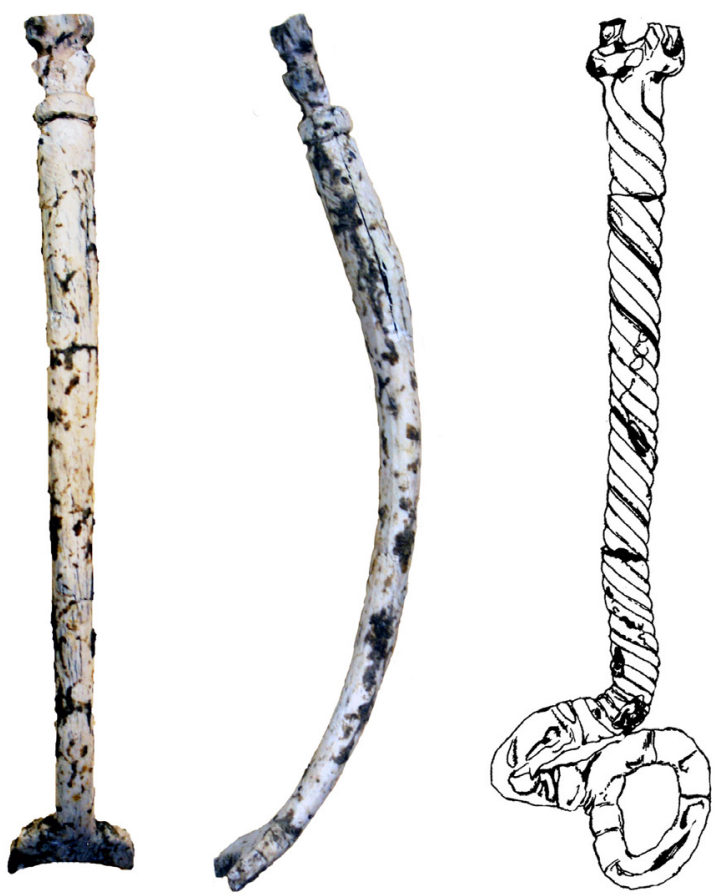

Fig. 9. Bone and glass distaffs that had been exposed to high temperatures (DCV)

Сл. 9. Преслице са интензивним траговима горења: примерци од кости и стакла (ДЦВ)

\section{Spindles}

Spindles consist of a shaft in the shape of a needle with both ends pointed, and a thick part usually located at one-third of the length of the spindle, and the spindle whorl secured at the thickest part of the shaft.

Viminacium yielded nine spindles in total, which is significantly less than the number of distaffs (61 made out of various materials). Reasons for such a situation should be sought in the possibility that the majority of spindles were manufactured out of wood, which couldn't be preserved. Wooden spindles are known from Egypt (Walker et al. 1997, 253), where six of them, together with spindle whorls, have been found in a grave of a young woman (Спасић-Ђурић 2007, 182-183). The other possibility that has to be taken into consideration is that a spindle whorl could have come off the spindle, making it hard to distinguish the shaft of the spindle from a pin.

Spindles discovered in Viminacium were all made of bone and were, as a rule, parts of grave assemblages. Five specimens have spindle whorls still in place (three made of bone, one of stone and one of glass). An interesting trait that can be 
observed in these five spindles is that their upper part is shaped in the form of an arrow (Fig. 8). Analogous artefacts are known from several other locations. Two specimens originate from burials discovered in Stobi in North Macedonia (Kovancaliev 2018), two from Salona in Croatia (Ivčević 2002a, 474; Ivčević 2002b, 213), and one from an unknown site in Hungary (Biró 1994, P1. XXXIII, 368).

\section{The functionality of bone spinning implements}

Having in mind that hand distaffs, at least in some parts of the Roman world, are most commonly discovered in graves, exclusively in ones belonging to females, there is a stance in contemporary academic discourse that these were objects of purely ritual character (Buljević 2002, 299; Bíró et al. 2012, 22, Danković 2019). Specimens from Viminacium confirm the overwhelming role of bone spinning tools in funerary practices. Out of the total number of 50 bone distaffs from this site, as many as 32 were found in graves ( 28 belonging to cremated individuals, and only four placed with inhumed deceased), and further 14 from the territory of cemeteries. It can be assumed that the latter were dislocated from their original contexts during the cleaning of the necropolis and devastation of graves by digging new ones. It has already been mentioned that all of the spindles were found in burials. Only four distaffs from Viminacium originate from contexts that are not sepulchral. The deposition of a distaff and four clay lamps in the area of the amphitheatre of Viminacium particularly stands out, given its possible ritual significance.

Similar situations have been recorded in other parts of the Empire, whenever circumstances of finds are available. Examples of distaffs that had been found in profane contexts are very rare, at least in the literature available to the author of this paper. The corpus of 13 specimens originating from the residential part of ancient Ephesus in Turkey will be addressed once more in this paper. Single distaffs have been found inside a tower in the fortlet Castrum Novae in Serbia (Васић 1984, 106, 109), at the acropolis of Stobi in North Macedonia (Kovancaliev 2019, 127), and in the so-called "Edifice with Apse" in Roman and Early Byzantine fort of Capidava in Romania (Raţiu 2016). The last-mentioned specimen is of significantly later date than most of the bone distaffs and has been dated into the $6^{\text {th }}$ century. Rare finds from profane contexts are not in any way a definitive proof of the everyday use of bone distaffs, so we need to analyse them from a functional perspective in order to try and come to any conclusions.

As it has already been stated, considerable skills required for the manufacture of these items, as well as the costliness and/or fragility of the ones made out of amber, jet, glass, ivory, and precious metals, all speak in favour of the ritual 
role of such spinning equipment. Bone distaffs, albeit more financially affordable, are still too small to serve for the spinning of a significant amount of yarn. Kovancaliev considers their thickness, ranging from 0.4 to $0.7 \mathrm{~cm}$, too thin and fragile to withstand the weight of a spindle with spindle whorl and spun thread (Kovancaliev 2019, 129). Other authors think that at least the distaffs with figural decorations on their tops represent objects of symbolical, rather than utilitarian character (Bíró 1994, 208-212; Ivčević 2000, 474).

On the other hand, some of the bone spinning tools possess certain elements that can be explained only from the functional standpoint. First of them is, of course, the ring-shaped bottom part of numerous distaffs, which was intended to secure a firmer grip during the process of spinning. Spirally fluted bodies, which are a very common feature, as well as jagged edges on one specimen from Viminacium (Fig. 13), could be explained by the need to prevent rovings of wool from sliding downwards. The same reason would justify the presence of a central disc on some of the artefacts. However, an amber distaff from Viminacium (Danković 2019), whose functional value is pretty much out of the question in the author's opinion, also incorporates a discoid central pearl. A possible explanation is that these objects are in fact shrunk down but precise copies of implements that were actually used for the spinning of the wool.

The arrow-shaped top of some of the spindles could have had the function of firmly attaching the thread coming from the distaff. It is interesting to note that this type of artefacts is still unknown from contexts that are not sepulchral, as far as the author of this paper is aware. It is possible that some of the wooden spindles, used in day-to-day activities, had metal hooks attached to the top (Kovancaliev 2019, 129). A similar function can be attributed to the incised notch on one of the spindles from Salona (Ivčević 2002a, 474; Ivčević 2002b, 214).

Possible use-wear marks are rarely taken into consideration when spinning tools are discussed and published. It is stated that bone distaffs from Sirmium in Serbia with tops modelled in the form of a woman's head show marks of use. Namely, the author informs us that backs of the heads are polished due to their role as sticks for smearing perfumes (Шарановић-Светек 1981, 156). The only specimen that shows use-wear marks on the lower part of the shaft and the ring is the already mentioned distaff from Capidava (Raţiu 2016, 138). This is a particularly puzzling artefact, given that its top is modelled in the form of the goddess Venus. Such bone distaffs are considered to be amongst the least likely to have been actually used. Another intriguing detail is a very late dating of this object, which has been found on the floor of a $6^{\text {th }}$ century house. ${ }^{7}$

\footnotetext{
${ }^{7}$ Bone distaffs and spindles from Viminacium are dated into the period from the end of the $1^{\text {st }}$ until the mid- $3^{\text {rd }}$ century, with the bulk of the finds coming from the $2^{\text {nd }}$-century contexts. The type of distaffs with the depiction of Venus Pudica, such as the one from Capidava, were produced during the period from the end of the $1^{\text {st }}$ until the end of the $4^{\text {th }}$ century (Ivčević 2000, 477; Raţiu 2016, 139-140).
} 


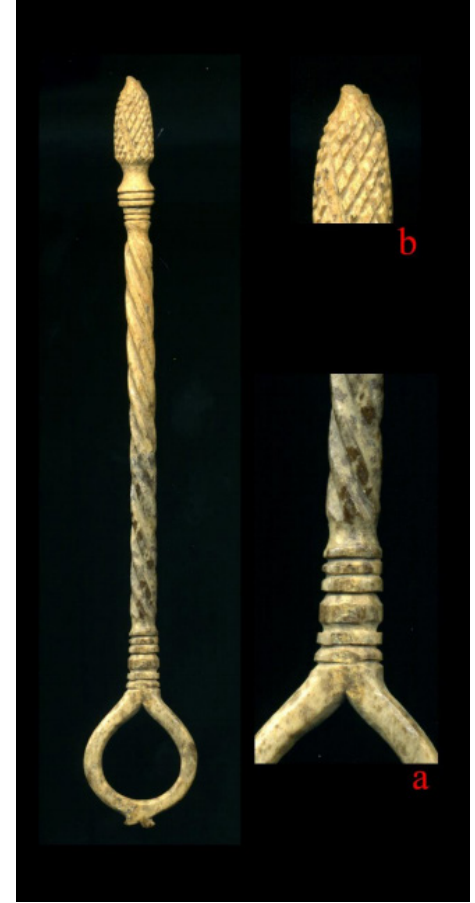

Fig. 10. Bone distaff from the amphitheatre of Viminacium, Serbia (Photo: Goran Stojić)

Сл. 10. Преслица од кости откривена на простору виминацијумског амфитеатра (Фотографија: Горан Стојић)

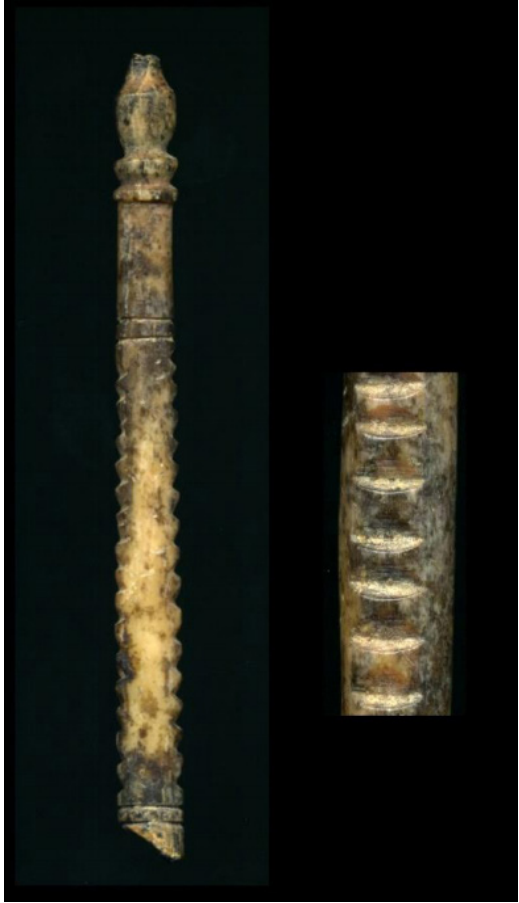

Fig. 11. Bone distaff from the northeastern necropolis of Viminacium, Serbia (Photo: Goran Stojić)

Сл. 11. Преслица од кости откривена на простору североисточне некрополе Виминацијума (Фотографија: Горан Стојић)

In order to acquire data regarding use-wear marks, which could help in pursuit of answers to the questions at hand, some of the distaffs discovered in Viminacium have been studied under magnification at the Laboratory for Bioarchaeology at the Faculty of Philosophy in Belgrade. ${ }^{8}$ For this purpose, a stereo microscope from Italian manufacturer Bio-Optica was used, with a maximum magnification of $45 \mathrm{x}$.

The main assumption was that the detection of possible use-wear marks was most likely on ring ends of distaffs, whose inner loop would be polished because of being repeatedly put on of the finger and held. Traces of such manipulation couldn't be observed on available specimens. Figure 10 shows a distaff

\footnotetext{
${ }^{8}$ I would like to express my gratitude to Dr Vesna Dimitrijević and Dr Sonja Vuković of the Department of Archaeology at the Faculty of Philosophy in Belgrade, for the opportunity of examining bone distaffs at the Laboratory for Bioarchaeology, as well as for useful suggestions during that process.
} 
made of a long bone of a large mammal. The ring in the bottom part was drilled through, and then additionally shaped with a sharp tool. This process produced clearly visible facets and rough edges (Fig. 10a). It is to be expected that these would be worn out if the object was continuously put on the finger during the spinning. This distaff is a very good example, given that it doesn't originate from a grave, but from the amphitheatre of Viminacium, so it is more probable that it was used during everyday activities.

The same distaff was suitable for trying to detect the existence of usewear marks that could have been formed during the supposed smearing of perfumed ointments. The top, shaped in the form of a pinecone, is decorated with crosshatched incisions. Once again, no visible signs of wear could have been observed (Fig. 10b).

The specimen discovered on the territory of the north-eastern necropolis of Viminacium, in a pit filled in during the cleaning of the necropolis, was considered appropriate for observing the traces that could originate from tying of rovings of wool to the shaft, as well as from extracting the fibres from the rovings. Sides of the body of this particular object are jagged, which has already been described as a possible functional trait. Figure 11 shows that only rough facets made by a sharp tool can be observed inside these notches, with the absence of use-wear traces.

\section{Conclusion}

As it was shown, there is no compelling evidence that bone spinning equipment was actually used during everyday activities in Viminacium. It is more probable that these are, in fact, objects of purely symbolical and ritual character. A question that needs to be addressed is whether bone distaffs and spindles were produced for the needs of funeral ceremonies or they were parts of personal belongings of women during their lives. Mentions of wool spinning implements by ancient writers might be rare, but they can lead to the answer we seek. During the procession that led from the house of the bride to the one where she would be living after the wedding (deductio in domum mariti), the girl was holding a distaff and a spindle in her hands (D'Ambra 2007, 75). Both Pliny the Elder and Plutarch inform us of this custom (Plin. El. Nat. VIII.74; Plut. Quaes. Rom. 31).

One can assume that luxurious, ritual spinning equipment was acquired especially to be used during such an important event in life (Facsàdy 2009, 690), simultaneously highlighting the prestige of the bride's family. Later in life, lavish distaffs were probably amongst the most prized possessions of the matron and could have been used during public appearances to communicate the status, or 
in front of guests and clients in domus, symbolically expressing the care for the household. The group of distaffs discovered in the residential neighbourhood in ancient Ephesus is particularly informative in this regard, given that all of the specimens were discovered in public spaces within houses (Trink1 2005, 300-302).

Lavish spinning equipment, being very personal in nature, was deposited in graves of deceased women. In this way, it was confirmed for the last time that she took care of the household and the family and that she was the embodiment of female virtue. Given that these objects were used during wedding ceremonies, their appearance in funerary contexts could point out the marital status of a buried individual, an information which would otherwise stay beyond the reach of archaeologists.

\section{ABBREVIATIONS}

CIL - Corpus inscriptionum Latinarum

DCV - Documentation Center Viminacium

\section{PRIMARY SOURCES}

Plin. El. Nat. - Gaius Plinius Secundus, Historia Naturalis. The Natural History of Pliny (trans. by J. Bostock and H. T. Riley), London: Henry G. Bohn, 1855.

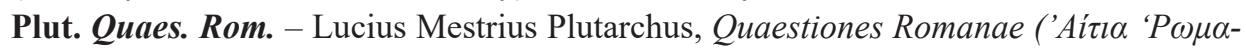
ïKó). Plutarch's Moralia in fifteen volumes, IV 263d-351b (trans. by F. C. Babbit), Cambridge, MA: Harvard University Press; London: William Heinemann LTD, 1962.

\section{REFERENCES}

Allason-Jones, L. 2005. Women in Roman Britain, Bootham: The Council for British Archaeology.

Audollent, A. 1923. Les tombes gallo-romaines à inhumation des Martres-de-Veyre (Puy-de-Dôme), in Mémoires présentés par divers savants à l'Académie des inscriptions et belles-lettres de l'Institut de France, Premiere série, Sujets divers d'érudition. Tome 13, $1^{\mathrm{e}}$ partie, 275-328.

Aurisicchio, C. Ferro, D. Martinelli G. Nunziante Cesaro, S. and Rapinesi, I. A. 2002. A study of a distaff of the second century A.D. from a necropolis of Boccone D'Aste (Roma, Italy) - tomb 75, Journal of Cultural Heritage 3, 107-116.

Bíró, M. 1994. The Unknown Goddess of Late-Roman popular Religious Belief, Acta Archaeologica Academiae Scientiarum Hungaricae, Tomus XLVI, 195-229.

Bíró, M. 1996. The bone objects of the Roman collection, Budapest: Magyar Nemzeti Múzeum. 
Bíró, M. Choyke, A. M. Lóránt, V. Ádám, V. 2012. Bone Objects in Aquincum, Budapest: Az Aquincumi Múzeum Gyüjteménye 2.

Buljević, Z. 2002. Stakleni štapići, in E. Marin (ed.) Longae Salonae, Split: Arheološki muzej, 297-311.

Carroll, M. 2013. The Insignia of Women: Dress, Gender and Identity on the Roman Funerary Monument of Regina from Arbeia, Archaeological Journal, 169, 281-311.

D’Ambra, E. 2007. Roman Women, New York: Cambridge University Press.

Danković, I. 2019. Burial of a Woman with an Amber Distaff at Viminacium, Starinar LXIX/2019, 215-229.

Facchinetti, G. 2005. La Rocca, La signora del sarcofago, 199-223; 333-334.

Facsády, A. R. 2008. Glass Distaff From Aquincum: Symbol or Tool?, ANODOS Studies of the Ancient World 8, 165-174.

Facsády, A. R. 2009. La représentation de la femme sur les stéles funéraires romaines du musée d'Aquincum (Budapest), in V. Gaggadis-Robin, A. Hermary, M. Reddé et C. Sintés (eds.), Actes du Xe colloque international sur l'art provincial romain (Arles-Aix, 21-23 mai 2007), Arles, 683-691.

Fremersdorf, F. Polonyi-Fremersdorf, E. 1984. Die Farblosen Gläser der Frühzeit in Köln, Köln: Archäologische Gesellschaft Köln.

Gagetti, E. 2006. Locum in delicii... sucina optinent. Le ambre di Aquileia e di Spalato, Le regioni di Aquileia e Spalato in epoca Romana, Castello di Udine: Fondazione Cassamarca, 135-162.

Gines Taylor. C. 2018. Late Antique Images of the Virgin Annunciate Spinning: Allotting the Scarlet and the Purple, Leiden: Brill.

Голубовић, С. 2000. Обућа из триконхалне гробнице из Виминацијума, Viminacivm 11, 83-100.

Gottschalk, R. 1996. Ein Spätrömischer Spinnrocken aus Elfenbein, Archäologisches korrespondenzblatt 26, 483-500.

Ivčević, S. 2000. Koštane preslice s prikazom Afrodite iz Arheološkog muzeja Split (Summary: Bone distaffs with depictions of the goddess Aphrodite in the Archaeological museum in Split), Opvscvla Archaeologica Vol. 23-24, No. 1 (1999-2000), 473-480.

Ivčević, S. 2002a. Predmeti za šivanje, tkanje i predenje, Longae Salonae, Vol. I, Split: Arheološki muzej, 469-481.

Ivčević, S. 2002b. Predmeti za šivanje, tkanje i predenje, Longae Salonae, Vol. II, Split: Arheološki muzej, 212-216.

Јевремовић, Н. 1996. Прилог проучавању посебне групе коштаних инструмената из Збирке Дуњић, Зборник Народног музеја XVI-1, 225-232.

Korać, M. Golubović S. 2009. Viminacium, Više Grobalja, Tom 2, Beograd: Arheološki institut.

Kovancaliev, Z. 2019. Roman and Late Roman bone spinning tools from Stobi, Macedonia, CPAG 29, 2019, 119-131.

Larsson Lovén, L. 1998. Lanam fecit - Woolworking and Female Virtue, Aspects of Woman in Antiquity, 85-95; T. XVI-XX. 
Микулчић, И. 1975. Раноримски скелетни гробови из Скупа, Старинар XXIVXXV, 89-102.

Pásztókai-Szeőke, J. 2011. “The Mother Shrinks, The Child Grows. What Is It?” The Evidence of Spinning Implements in Funerary Context from the Roman Province of Pannonia, Mujer y vestimentia, Aspectos de la identidad femeninala antigüedad, Valencia: Sema, 125-140.

Pásztókai-Szeőke, J. Radman-Livaja, I. 2013. [2015]. Textilmühely az Iseum területén. In: O.Sosztarits, P. Balázs, A. Csapláros (eds.) A savariai Isis szentély I. Isis savariai otthona -kiállítási katalógus, Sistrum - Serie A, No. 1. Szombathely, 255-268.

Petković, S. 1995. Rimski predmeti od kosti i roga sa teritorije Gornje Mezije, Beograd: Arheološki institut.

Rădulescu, A. Coman, E. Stavru, C. 1973. “"Un sarcofago di età Romana scoperto nella necropoli tumulare di Callatis (Mangalia)", Pontica VI, 247-265.

Rațiu, A. 2016. Venus Pudica on a bone distaff from Capidava, Cercetări Arheologice, XXIII, MNIR, 137-150.

Ропкић, А. 2006. Стаклени инструменти-мешалице из Виминацијума, Гласник Српског археолошког друштва 22, 375-380.

Ružić, M. 1994. Rimsko staklo u Srbiji, Beograd: Filozofski fakultet.

Sebesta, J. L. 2001. Symbolism in the Costume of Roman Women, in J. L. Sebesta and L. Bonfante (eds.) The World of Roman Costume, Madison: The University of Wisconsin Press, 46-53.

Smith, W. LL. D. (Ed.) 1859. Dictionary of Greek and Roman Antiquities, Boston: Little, Brown, and Company.

Спасић-Ђурић, Д. 2007. Медаљон и други налази из гроба Г-1733 из Виминацијума, Гласник Српског археолошког друштва 23, 323-340.

Стаменковић, С. Иванишевић, В. Пешић, Ј. 2016. Римска некропола у Малој Копашници, у С. Перић и А. Булатовић (ур.) Археолошка истраживања на аутопуту E75 (2011-2014), Београд: Археолошки институт, 17-46.

Шарановић-Светек, В. 1981. Типологија коштаних предмета из Сирмијума, Рад војвођанских музеја 27, 149-179.

Špehar, P. 2010. Materijalna kultura iz ranovizantijskih utvrđenja u Đerdapu, Beograd: Arheološki institut.

Thurston Peck, H. (Ed.) 1898. Harper's Dictionary of Classical Antiquities, New York: Harper \& Brothers.

Trinkl, E. 1994. Ein Set aus Spindel, Spinnwirtel und Rocken aus einem Sarkophag in Ephesos, ÖJh 63 Beiblatt, 80-86.

Trinkl, E. 2000. "Die spinnen, die Römerinnen", in L. Dollhofer u. a. (Hrsg.), Altmodische Archäologie. Festschrift F. Brein, Forum Archaeologiae 14/III/2000, (http://farch. net - accessed 08.05.2020).

Trinkl, E. 2005. Zum Wirkungskreis einer kleinasiatischen matrona anhand ausgewählter aus dem Hanghaus 2 in Ephesos, Jahreshefte des Österreichischen Archäologischen Institutes in Wien 1 (73), 281-304. 
Васић, М. 1984. Чезава - Castrum Novae, Старинар XXXIII-XXXIV, 91-122.

Walker, S. Bierbrier, M. Roberts, P. Taylor, J. 1997. Fayum: Misteriosi Volti Dall'Egitto, Roma: Leonardo Arte.

Wasowicz, A. 1987. Deux aspects de l'art funéraire dans les antiquités du Bosphore cimmérien, La revue du Louvre et des musées de France, No. 4, 268-277.

Зотовић, Љ. Јордовић, Ч. 1990. Viminacivm 1, Некропола Више гробаља, Београд: Археолошки институт. 


\title{
Илија Данковић
}

Археолошки институт Београд

\section{РИМСКИ КОШТАНИ ПРИБОР ЗА ПРЕДЕЊЕ ВУНЕ: ДА ЛИ ЈЕ БИО ФУНКЦИОНАЛАН?}

\author{
Кључне речи: римски прибор за предење вуне, \\ преслице од кости, вретена од кости, Виминацијум
}

Римске коштане алатке за предење вуне дуго су представљале запостављени део материјалне културе античког периода, што је у вези са генералним недостатком интересовања за све теме које се не тичу доминантних наратива археологије класичног периода, тј. такозваног мушког домена. Последица такве ситуације је да су ручне преслице неретко тумачене на погрешне начине, као козметички штапићи за наношење миришљавих масти или игле за високу пунђу, што је доприносило продубљивању и јачању стереотипа о женама у антици. Нажалост, таква пракса је и даље спорадично присутна у домаћој стручној литератури.

Захваљујући бројним визуелним сведочанствима на надгробним споменицима као и све већем броју налаза преслица и вретена у јасно дефинисаним контекстима, отклоњена је свака сумња о томе да се ради о алаткама за предење. Међутим, готово искључиво јављање ових предмета у целинама сепулкралног карактера, те њихова минуциозна израда и фрагилност, навели су одређен број аутора на закључак да се ради о предметима симболичке вредности и ритуалног карактера, који нису могли бити коришћени у свакодневним активностима. Такве тврдње додатно су поткрепљене постојањем изузетно луксузних прибора за предење, израђених од ћилибара, гагата, слоноваче, стакла и племенитих метала, који показују идентичну дистрибуцију у археолошком регистру.

С друге стране, примерци од кости недвосмислено поседују елементе који се не могу објаснити другачије него са функционалног становишта. У питању су централни дискови, тордирана тела и прстенови за сигурније држање код преслица, као и врхови у виду стрелице код вретена.

У овом раду је извршен покушај систематизације свих сазнања о коштаном прибору за предење вуне, те су у обзир узета сведочанства визуелне културе о процесу предења у антици, услови налаза, морфолошке карактеристике артефаката, као и евентуални трагови употребе на самим алаткама. Посебан осврт начињен је на корпус налаза из античког Виминацијума, бу- 
дући да је овај локалитет изнедрио једну од највећих колекција прибора за предење на територији целог Царства (50 преслица и 9 вретена од кости).

С обзиром на тренутни степен истражености, може се закључити да не постоје убедљиви докази о коришћењу коштаних алатки за предење у свакодневном процесу обраде вуне у Виминацијуму. Вероватније је да су биле средство за слање симболичке поруке о жени као чуварки домаћинства, која је својим врлинама гарантовала опстанак породице, основне јединице у структури римског друштва. Будући да је из историјских извора познато да су преслица и вретено били неизоставни део свадбене процесије, може се претпоставити да су луксузни, минијатурни примерци прибора за предење прибављани управо за ову прилику, те да су остајали у поседу жене до краја њеног живота и бивали положени у гроб након смрти. 